Juan M. Saavedra, Walter Häuser, Gladys Ciuffo, Giorgia Egidy, Kwang-Lae Hoe, Olaf Jöhren, Takaaki Sembonmatsu, Tadashi Inagami and Inés Armando

Am J Physiol Renal Physiol 280:71-78, 2001.

You might find this additional information useful...

This article cites 43 articles, 11 of which you can access free at:

http://ajprenal.physiology.org/cgi/content/full/280/1/F71\#BIBL

This article has been cited by 6 other HighWire hosted articles, the first 5 are:

Sex and the renin-angiotensin system: inequality between the sexes in response to RAS stimulation and inhibition

J. C. Sullivan

Am J Physiol Regulatory Integrative Comp Physiol, April 1, 2008; 294 (4): R1220-R1226.

[Abstract] [Full Text] [PDF]

AT1 Receptor Blockade Regulates the Local Angiotensin II System in Cerebral

Microvessels From Spontaneously Hypertensive Rats

J. Zhou, J. Pavel, M. Macova, Z.-X. Yu, H. Imboden, L. Ge, T. Nishioku, J. Dou, E. Delgiacco and J. M. Saavedra

Stroke, May 1, 2006; 37 (5): 1271-1276.

[Abstract] [Full Text] [PDF]

Intronic ANG II type 2 receptor gene polymorphism 1675 G/A modulates receptor protein expression but not mRNA splicing

C. Warnecke, P. Mugrauer, D. Surder, J. Erdmann, C. Schubert and V. Regitz-Zagrosek

Am J Physiol Regulatory Integrative Comp Physiol, December 1, 2005; 289 (6): R1729-R1735.

[Abstract] [Full Text] [PDF]

Pressure Natriuresis in AT2 Receptor-Deficient Mice with L-NAME Hypertension

M. Obst, V. Gross, J. Janke, M. Wellner, W. Schneider and F. C. Luft

J. Am. Soc. Nephrol., February 1, 2003; 14 (2): 303-310.

[Abstract] [Full Text] [PDF]

Estrogen upregulates renal angiotensin II AT2 receptors

I. Armando, M. Jezova, A. V. Juorio, J. A. Terron, A. Falcon-Neri, C. Semino-Mora, H.

Imboden and J. M. Saavedra

Am J Physiol Renal Physiol, November 1, 2002; 283 (5): F934-F943.

[Abstract] [Full Text] [PDF]

Medline items on this article's topics can be found at http://highwire.stanford.edu/lists/artbytopic.dtl on the following topics:

Biochemistry .. Angiotensin II

Physiology .. Kidneys

Physiology .. Glomerulus

Medicine .. Genes

Medicine .. Kidney Glomerulus

Physiology .. Mice

Updated information and services including high-resolution figures, can be found at:

http://ajprenal.physiology.org/cgi/content/full/280/1/F71

Additional material and information about AJP - Renal Physiology can be found at:

$\mathrm{http}: / /$ www.the-aps.org/publications/ajprenal

This information is current as of March 27, 2009 .

AJP - Renal Physiology publishes original manuscripts on a broad range of subjects relating to the kidney, urinary tract, and their respective cells and vasculature, as well as to the control of body fluid volume and composition. It is published 12 times a year (monthly) by the American Physiological Society, 9650 Rockville Pike, Bethesda MD 20814-3991. Copyright @ 2005 by the

American Physiological Society. ISSN: 0363-6127, ESSN: 1522-1466. Visit our website at http://www.the-aps.org/. 


\title{
Increased $\mathrm{AT}_{1}$ receptor expression and mRNA in kidney glomeruli of $\mathrm{AT}_{2}$ receptor gene-disrupted mice
}

\author{
JUAN M. SAAVEDRA, ${ }^{1}$ WALTER HÄUSER,${ }^{1}$ GLADYS CIUFFO,${ }^{1}$ GIORGIA EGIDY,${ }^{1}$ \\ KWANG-LAE HOE, ${ }^{1}$ OLAF JÖHREN, ${ }^{1}$ TAKAAKI SEMBONMATSU, ${ }^{2}$ \\ TADASHI INAGAMI, ${ }^{2}$ AND INÉS ARMANDO ${ }^{1}$ \\ ${ }^{1}$ Section on Pharmacology, National Institute of Mental Health, Bethesda, Maryland 20892; and \\ ${ }^{2}$ Vanderbilt University, Department of Biochemistry, School of Medicine, Nashville, Tennessee 37232 \\ Received 5 April 2000; accepted in final form 29 September 2000
}

\begin{abstract}
Saavedra, Juan M., Walter Häuser, Gladys Ciuffo, Giorgia Egidy, Kwang-Lae Hoe, Olaf Jöhren, Takaaki Sembonmatsu, Tadashi Inagami, and Inés Armando. Increased $\mathrm{AT}_{1}$ receptor expression and mRNA in kidney glomeruli of $\mathrm{AT}_{2}$ receptor gene-disrupted mice. Am J Physiol Renal Physiol 280: F71-F78, 2001.-The proposed feedback between angiotensin II $\mathrm{AT}_{2}$ and $\mathrm{AT}_{1}$ receptors prompted us to study $\mathrm{AT}_{1}$ receptor expression in kidneys of male $\mathrm{AT}_{2}$ receptor-gene disrupted mice (agtr2 -/y). In wild-type (agtr2 $+/ \mathrm{y})$ mice, $\mathrm{AT}_{1}$ receptor binding and $\mathrm{mRNA}$ is abundant in glomeruli, and $\mathrm{AT}_{1}$ receptor binding is also high in the inner stripe of the outer medulla. $\mathrm{AT}_{2}$ receptors are scarce, primarily associated to cortical vascular structures. In agtr2 -/y mice, $\mathrm{AT}_{1}$ receptor binding and $\mathrm{mRNA}$ were increased in the kidney glomeruli, and $\mathrm{AT}_{1}$ receptor binding was higher in the rest of the cortex and outer stripe of the outer medulla, but not in its inner stripe, indicating different cellular regulation. Although $\mathrm{AT}_{2}$ receptor expression is very low in male agtr $2+/ \mathrm{y}$ mice, their gene disruption alters $\mathrm{AT}_{1}$ receptor expression. $\mathrm{AT}_{1}$ upregulation alone may explain the $\mathrm{AT}_{2}$ gene-disrupted mice phenotype such as increased blood pressure, higher sensitivity to angiotensin II, and altered renal function. The indirect $\mathrm{AT}_{1} / \mathrm{AT}_{2}$ receptor feedback could have clinical significance because $\mathrm{AT}_{1}$ antagonists are widely used in medical practice.
\end{abstract}

renin-angiotensin system; angiotensin II receptor types; gene-disrupted models

ANGIOTENSIN II (ANG II), by stimulation of specific, discretely localized ANG II receptors, plays a crucial role in the modulation of renal function in mammals (31). ANG II receptors are classified into $\mathrm{AT}_{1}$ and $\mathrm{AT}_{2}$ types on the basis of their relative affinity for nonpeptidic-selective ligands (46) and molecular cloning (16, 19, 39). Most of the known actions of ANG II on the regulation of water and salt metabolism are dependent on stimulation of $\mathrm{AT}_{1}$ receptors $(31,46)$. In the kidney, stimulation of $\mathrm{AT}_{1}$ receptors by ANG II modulates both glomerular and tubular function including sodium retention, vasoconstriction of renal vessels, and decreased glomerular filtration rate (2).

\footnotetext{
Address for reprint requests and other correspondence: J. M. Saavedra, Section on Pharmacology, National Institute of Mental Health, Center Dr. MSC 1514, Bldg. 10, Rm. 2D-57, Bethesda, MD 20892 (E-mail: Saavedrj@irp.nimh.nih.gov).
}

$\mathrm{AT}_{1}$ receptors are present in large numbers in the adult mammalian kidney, with a major expression in the glomeruli, and lower levels in the renal cortical tubules, vasculature, medullar interstitial cells, and collecting ducts $(1,4,6,22,23,30,36,38,40)$. Of the two $\mathrm{AT}_{1}$ receptor subtypes existing in rodents, $\mathrm{AT}_{1 \mathrm{~A}}$ and $\mathrm{AT}_{1 \mathrm{~B}}$, the $\mathrm{AT}_{1 \mathrm{~A}}$ receptors predominate in the kidney (22). In adult rodents, kidney $\mathrm{AT}_{2}$ receptors were reported to be absent $(4,23,41)$ or present at low levels $(18,38)$. Other studies reported a selective association of $\mathrm{AT}_{2}$ receptors in the adult kidney from different species, including humans, with vascular structures (8, $9,10,30,49)$. The localized and restricted expression of $\mathrm{AT}_{2}$ receptors in association with renal arteries strongly suggested a function of $\mathrm{AT}_{2}$ receptors different from that of $\mathrm{AT}_{1}$ receptors, perhaps related to inhibition of angiogenesis and vasodilation $(3,34)$.

The availability of animal models with targeted disruption of specific genes provided an opportunity to further analyze the possible role of $\mathrm{AT}_{2}$ receptors. The targeted disruption of the mouse $\mathrm{AT}_{2}$ receptor gene significantly increased blood pressure and the sensitivity to the pressor action of ANG II, indicating an enhanced response to $\mathrm{AT}_{1}$ receptor stimulation (15, 17). We asked the question whether absence of $\mathrm{AT}_{2}$ receptor transcription could result in alterations in $\mathrm{AT}_{1}$ receptor binding or mRNA expression in selected areas of the kidney in this mouse model.

\section{MATERIALS AND METHODS}

Animals. Mice were obtained form the Department of Biochemistry, Nashville University, and were kept under controlled conditions with free access to water and food, according to protocols approved by National Institute of Mental Health (NIMH) Animal Care and Use Committee. We produced the agtr2 gene-disrupted mice by the injection of agtr2 disrupted embryonic stem cells (E14-1) from the 129 Ola mouse line into blastocyts derived from $\mathrm{C} 57 \mathrm{BL} / 6$ mice, as described previously (17). After the genotype of $\mathrm{F}_{2}$ heterozygous females (agtr2 -/+) was clearly confirmed, they were backcrossed with C57BL/6 wild-type males for three genera-

The costs of publication of this article were defrayed in part by the payment of page charges. The article must therefore be hereby marked "advertisement" in accordance with 18 U.S.C. Section 1734 solely to indicate this fact. 
tions. Littermate gene-disrupted (agtr2 $-/ \mathrm{Y})$ and control wild-type $($ agtr2 $+/ \mathrm{Y})$ males were selected from the third backcross progeny to minimize the effect of differences in genetic background.

Mice were transported to NIMH, kept for 1 day under controlled conditions as above, and killed by decapitation between 10:00 AM and 11:00 AM. Kidneys were immediately removed, frozen in isopentane at $-30^{\circ} \mathrm{C}$, and stored at $-80^{\circ} \mathrm{C}$. For binding studies, sections $(16 \mu \mathrm{m})$ were cut in a cryostat at $-20^{\circ} \mathrm{C}$, thaw-mounted on gelatin-coated slides, and dried overnight in a desiccator at $4^{\circ} \mathrm{C}$. Sections were stored at $-80^{\circ} \mathrm{C}$ until binding experiments were performed. Consecutive sections were used for ANG II receptor binding studies and in situ hybridization. Every tenth section was stained with hematoxylin and eosin to localize the structures expressing the binding or the receptor mRNA. For in situ hybridization experiments, sections were collected on silanated glass slides (Digene Diagnostics, Beltsville, MD) and stored at $-80^{\circ} \mathrm{C}$.

ANG II receptor binding. Sar ${ }^{1}$-ANG II (Peninsula Laboratories, Belmont, CA) and CGP-42112 (Neosystems Laboratory, Strasbourg, France) were iodinated by New England Nuclear (Boston, MA) to a specific activity of $2,200 \mathrm{Ci} / \mathrm{mmol}$.

Adjacent kidney sections were preincubated for $15 \mathrm{~min}$ at $22^{\circ} \mathrm{C}$ in $10-\mathrm{mM}$ sodium phosphate buffer, $\mathrm{pH} 7.4$, containing $120 \mathrm{mM} \mathrm{NaCl}, 5 \mathrm{mM}$ EDTA, $0.005 \%$ bacitracin (Sigma, St. Louis, MO), and $0.2 \%$ protease-free BSA (Sigma), followed by incubation for $2 \mathrm{~h}$ at $22^{\circ} \mathrm{C}$ in fresh buffer, prepared as above with the addition of $50 \mu \mathrm{M}$ Plummer's inhibitor (Calbiochem, La Jolla, CA), $100 \mu \mathrm{M}$ phenylmethylsulfonyl fluoride (Sigma), $500 \mu \mathrm{M}$ phenantrolin (Sigma), and $0.5 \mathrm{nM}\left[{ }^{125} \mathrm{I}\right] \mathrm{Sar}^{1}$ ANG II. After an incubation for $120 \mathrm{~min}$ at $22^{\circ} \mathrm{C}$ the sections were washed four times for $1 \mathrm{~min}$ each in ice-cold $50 \mathrm{mM}$ Tris-HCl buffer ( $\mathrm{pH} 7.4$ ), followed by a $30 \mathrm{~s}$ wash in ice-cold water, and dried under a stream of cold air.

Binding of $\left.{ }^{125} \mathrm{I}\right] \mathrm{Sar}^{1}-\mathrm{ANG}$ II to $\mathrm{AT}_{1}$ receptors was determined in adjacent kidney sections as follows. Some sections were incubated with $0.5 \mathrm{nM}\left[{ }^{125} \mathrm{I}\right] \mathrm{Sar}^{1}$-ANG II to determine total binding. Adjacent sections were incubated as above with the addition of $10^{-5} \mathrm{M}$ losartan (DuPont-Merck, Wilmington, $\mathrm{DE}$ ), to displace binding to $\mathrm{AT}_{1}$ receptors. Binding to $\mathrm{AT}_{1}$ receptors was calculated as the difference between total binding and the binding remaining in adjacent sections incubated in the presence of excess concentration of losartan. Similarly, binding of $\left.{ }^{125} \mathrm{I}\right] \mathrm{Sar}^{1}-\mathrm{ANG}$ II to $\mathrm{AT}_{2}$ receptors was determined as the difference between total binding and binding in adjacent sections incubated in the presence of $10^{-6} \mathrm{M}$ of PD-123319 (Parke-Davis, Ann Arbor, MI) to selectively displace binding to $\mathrm{AT}_{2}$ receptors. The concentrations of the $\mathrm{AT}_{1}$ and $\mathrm{AT}_{2}$ receptor-selective ligands were selected to give maximum-specific displacement (13). Nonspecific or background binding was determined by incubating consecutive sections with $10^{-6} \mathrm{M}$ ANG II (Peninsula). The values remaining were subtracted from all determinations as described above. In the case of areas where we found binding only to $\mathrm{AT}_{1}$ receptors, the values obtained after displacement with excess concentrations of losartan were not significantly different from background values obtained by displacement with excess concentrations of unlabeled ANG II.

In addition, $\left[{ }^{125} \mathrm{I}\right] \mathrm{CGP}-42112$ binding was performed in another set of adjacent sections to confirm the presence or absence of $\mathrm{AT}_{2}$ receptors. At the concentrations used, $\left[{ }^{125} \mathrm{I}\right] \mathrm{CGP}-42112$ exclusively labels $\mathrm{AT}_{2}$, and not $\mathrm{AT}_{1}$, receptors (14). Buffers used in this assay had the same composition as those used for the binding with [ $\left.{ }^{125} \mathrm{I}\right] \mathrm{Sar}^{1}-\mathrm{ANG}$ II. Tissue sections were preincubated for $15 \mathrm{~min}$ in incubation buffer followed by incubation for $120 \mathrm{~min}$ in fresh buffer containing $0.2 \mathrm{nM}\left[{ }^{125} \mathrm{I}\right] \mathrm{CGP}-42112$. To determine specific binding to $\mathrm{AT}_{2}$ receptors, consecutive sections were incubated in the presence of $10^{-6} \mathrm{M}$ of PD-123319 to selectively displace binding to $\mathrm{AT}_{2}$ sites. Nonspecific binding was determined by incubating consecutive sections with $5 \times 10^{-6} \mathrm{M}$ of ANG II (Peninsula).

To further localize $\mathrm{AT}_{2}$ receptors histologically, $\left[{ }^{125} \mathrm{I}\right] \mathrm{CGP}$ 42112 binding was performed in 6 - $\mu \mathrm{m}$ thick kidney sections. Adjacent sections were stained with hematoxylin and eosin. After binding experiments, sections were fixed for $60 \mathrm{~min}$ in paraformaldehyde vapors at $80^{\circ} \mathrm{C}$ and dipped in photo emulsion. After exposure for $2 \mathrm{wk}$, sections were developed in Kodak D-19 developer for $3 \mathrm{~min}$ at $15^{\circ} \mathrm{C}$, fixed for $4 \mathrm{~min}$, and counter stained with hematoxylin and eosin.

To determine if the radio-labeled ligands could be significantly metabolized under the conditions of incubation, we analyzed aliquots of buffers obtained before and after incubation of kidney sections by reversed-phase high performance liquid chromatography as described earlier (13). No metabolism of the radio-labeled ligands was observed under the above-mentioned conditions (results not shown).

Quantitative receptor autoradiography. We exposed dry sections to Hyperfilm- ${ }^{3} \mathrm{H}$ (Amersham, Arlington Heights, IL) along with $16-\mu \mathrm{m}$ sections of autoradiographic ${ }^{125} \mathrm{I} \mathrm{mi}-$ croscales (Amersham) at $4^{\circ} \mathrm{C}$. Films were developed in icecold D-19 developer (Eastman Kodak, Rochester, NY) for 4 min, fixed in Kodak rapid fixer for $4 \mathrm{~min}$ at $22^{\circ} \mathrm{C}$, and rinsed in water for $15 \mathrm{~min}$. We measured optical densities in the autoradiograms by computerized microdensitometry by using the NIH Image 1.6 analysis system (NIMH, Bethesda, MD). For quantitative autoradiography, we measured the optical densities separately in kidney glomeruli, the rest of the cortex, and outer and inner stripes of the outer medulla. The optical densities were related to the concentration of radioactivity present in the sections by comparison with the ${ }^{125} \mathrm{I}$ microscales, and transformed to corresponding values of $\mathrm{fmol} / \mathrm{mg}$ protein (37). These values should be considered as arbitrary units, because the ligand concentrations used are below saturation, and because the actual protein-tissue-protein concentration varies between the different regions of the kidney (37). We found similar differences between groups when values were calculated as optical densities before comparison to ${ }^{125} \mathrm{I}$ standards.

In situ hybridization histochemistry. In situ hybridization was performed by using ${ }^{35}$ S-labeled antisense and sense (control) riboprobes (21). A 478-bp EcoR I/SacI cDNA fragment of rat $\mathrm{AT}_{1 \mathrm{~A}}$ receptor $(19,39)$ showing 95 and $88 \%$ sequence homology to the mouse $\mathrm{AT}_{1 \mathrm{~A}}$ and $\mathrm{AT}_{1 \mathrm{~B}}$ receptor cDNA, respectively, and 99.4 and $92.5 \%$ amino acid homology to mouse $\mathrm{AT}_{1 \mathrm{~A}}$ and $\mathrm{AT}_{1 \mathrm{~B}}$ receptors, respectively $(19,39)$, was subcloned into the pBluescript II KS+ vector. Riboprobes were labeled by in vitro transcription by using an RNA labeling kit (Amersham). Because we used a riboprobe to the coding region of the rat $\mathrm{AT}_{1}$ receptor that has a very high homology between $\mathrm{AT}_{1 \mathrm{~A}}$ and $\mathrm{AT}_{1 \mathrm{~B}}$-rodent subtypes, we did not determine the relative contribution of kidney $\mathrm{AT}_{1 \mathrm{~A}}$ or $\mathrm{AT}_{1 \mathrm{~B}}$ receptor subtypes in our experiments. However, over $95 \%$ of the renal $\mathrm{AT}_{1}$ receptors are of the $\mathrm{AT}_{1 \mathrm{~A}}$ subtype (22). Thus the mRNA data presented here predominantly reflects the regulation of the $\mathrm{AT}_{1 \mathrm{~A}}$ receptors.

Sections were fixed in $4 \%$ paraformaldehyde for $10 \mathrm{~min}$, acetylated for $10 \mathrm{~min}$ in $0.1 \mathrm{M}$ triethanolamine $\mathrm{HCl}, \mathrm{pH} 8.0$, containing $0.25 \%$ acetic anhydride, dehydrated in alcohols, and air dried. Each section was covered with $50-\mu l$ hybridization buffer containing $50 \%$ formamide, $0.3 \mathrm{M} \mathrm{NaCl}, 2 \mathrm{mM}$ EDTA, 20 mM Tris, pH 8.0, $1 \times$ Denhardt's solution, 10\% dextran sulfate, $100 \mu \mathrm{g} / \mathrm{ml}$ salmon sperm DNA, $250 \mu \mathrm{g} / \mathrm{ml}$ 
yeast tRNA, $150 \mathrm{mM}$ DTT, 0.1\% SDS, and 40,000-counts per minute/ $\mu \mathrm{l}$ sense or antisense probe. Sections were hybridized overnight at $54^{\circ} \mathrm{C}$, treated with $40 \mu \mathrm{g} / \mathrm{ml}$ RNase A (Sigma, St. Louis, MO) for $30 \mathrm{~min}$, and washed in sodium chloride/ sodium citrate (SSC) with increasing stringency. After a final wash in $0.1 \times \mathrm{SSC}$ at $65^{\circ} \mathrm{C}$ for $60 \mathrm{~min}$, sections were dehydrated through alcohols and exposed to Hyperfilm- ${ }^{3} \mathrm{H}$ (Amersham) along with ${ }^{14} \mathrm{C}$ microscales (Amersham) for 7 days. Films were developed as described above. The intensities of hybridization signals in kidney glomeruli, the rest of the cortex, and outer and inner stripes of the outer medulla, were quantified as $\mathrm{nCi} / \mathrm{g}$ tissue equivalent by measuring optical film densities by using the NIH Image 1.61 program. Data were calibrated with ${ }^{14} \mathrm{C}$ microscales after subtraction of the values obtained in the same areas of adjacent sections hybridized with sense (control) probes (nonspecific hybridization). The values obtained represent arbitrary units, because the protein content or weight of the different kidney areas may be different (32). We found similar differences between groups when values were calculated as optical densities before comparison to ${ }^{14} \mathrm{C}$ standards.

For cellular localization, slides were dipped in Kodak NTB2 photo emulsion, exposed for $4 \mathrm{wk}$, developed in Kodak $\mathrm{D}-19$ developer for $3 \mathrm{~min}$ at $15^{\circ} \mathrm{C}$, fixed for $4 \mathrm{~min}$, and counterstained with hematoxylin and eosin (Fisher Scientific, Fair Lawn, NJ).

Statistical analysis. Results were expressed as means \pm SE, calculated and analyzed by using GraphPad Prism (version 2.00) and Microsoft Excel (version 7.0a). Statistical analysis for values obtained from the displacement studies by using single concentrations of the displacers was performed by using a one-way ANOVA followed by post hoc analysis with the Newman-Keuls multiple comparison test. Mean \pm $\mathrm{SE}$ values of wild-type and $\mathrm{AT}_{2}$ gene-disrupted mice were compared for significance by using unpaired Student's $t$-test.

\section{RESULTS}

ANG II receptor subtype expression and $m R N A$ in wild-type mice. We studied ANG II receptor subtype binding and mRNA in the kidney of male wild-type and $\mathrm{AT}_{2}$ gene-disrupted mice. Binding to $\mathrm{AT}_{1}$ receptors was, as expected, high and selectively localized in the kidney of wild-type mice. In wild-type mice, the highest levels of losartan-sensitive, PD-123319-insensitive, $\left.{ }^{125} \mathrm{I}\right] \mathrm{Sar}^{1}-\mathrm{ANG}$ II binding to $\mathrm{AT}_{1}$ receptors were present on glomeruli (Fig. 1, A-E) and lower levels in the inner stripe of the outer medulla (Table 1). Binding to $\mathrm{AT}_{1}$ receptors was also present in the rest of the cortex and the outer stripe of the outer medulla (Table 1).

Emulsion autoradiography in wild-type mice revealed very high losartan-sensitive [ $\left.{ }^{125} \mathrm{I}\right] \mathrm{Sar}^{1}-\mathrm{ANG}$ II binding in kidney glomeruli and low, diffuse losartansensitive binding throughout the whole renal cortex (Fig. 2, $A-C$ ).

$\mathrm{AT}_{1}$ receptor mRNA was also detected in the kidney of male wild-type mice. As it was the case with $\mathrm{AT}_{1}$ receptor binding, $\mathrm{AT}_{1}$ receptor $\mathrm{mRNA}$ was higher in the glomeruli, and lower in the rest of the cortex and in the outer and inner stripes of the outer medulla (Table 1 and Fig. 3, $A$ and $B$ ). Low levels of $\mathrm{AT}_{1}$ mRNA expression were located in the renal vasculature (Fig. $3 C)$.

In some cortical structures of wild-type mice, of different shape and size than the glomeruli, we found high-losartan-insensitive, PD-123319-sensitive $\left[{ }^{125} \mathrm{I}\right] \mathrm{Sar}^{1}-\mathrm{ANG}$ II binding, indicative of $\mathrm{AT}_{2}$ re-
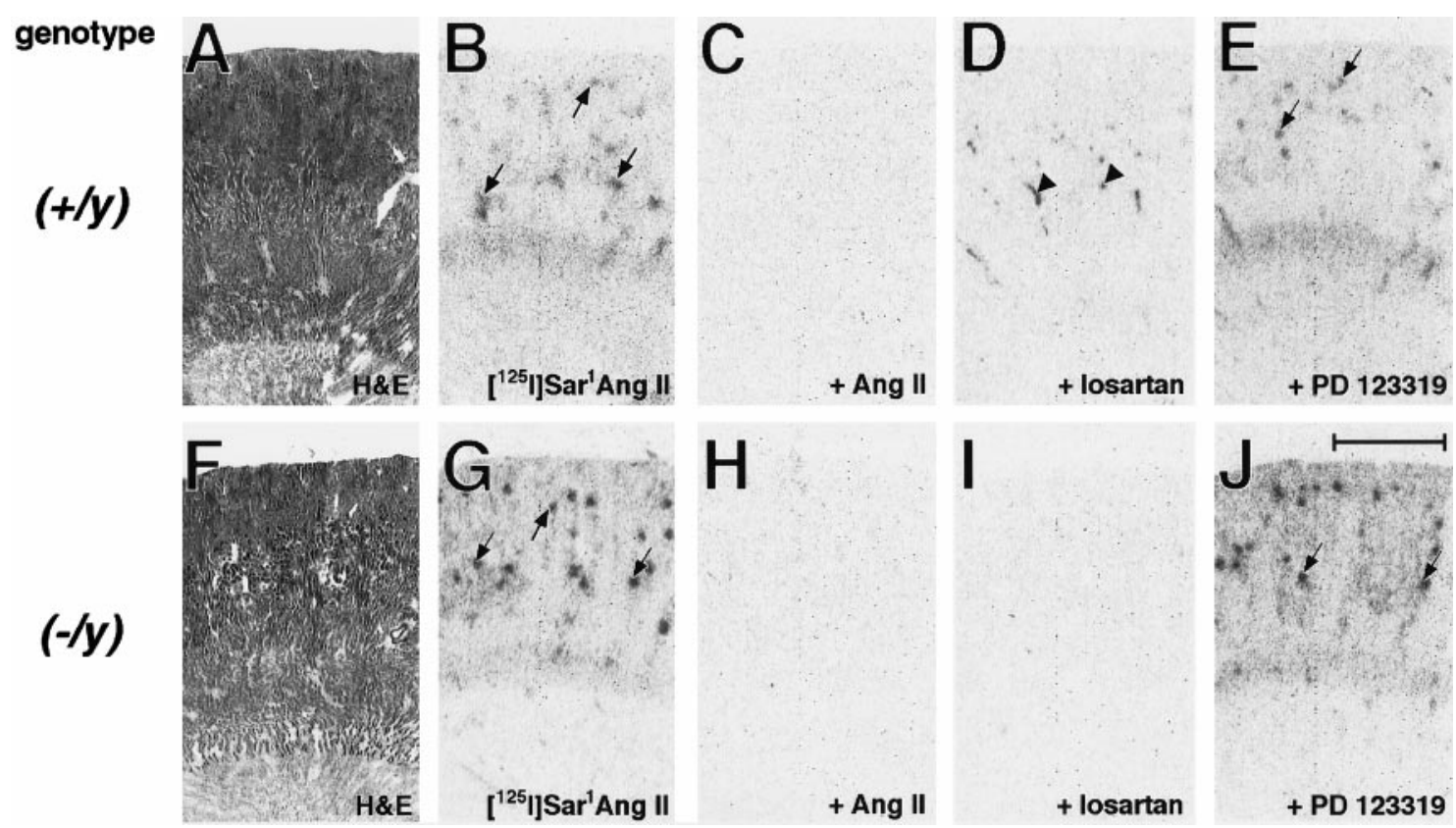

Fig. 1. Autoradiography of ANG II receptor type binding in kidneys from male mice. Hematoxylin-eosin (H \& E) staining [wild-type $(A), \mathrm{AT}_{2}$ gene deficient $\left.(F)\right]$ and autoradiographs with binding of $0.5 \mathrm{nM}\left[{ }^{125} \mathrm{I}\right]$ Sar ${ }^{1}$-ANG II in kidneys of wild-type $(+/ \mathrm{y})$ mice $(B-E)$ and $\mathrm{AT}_{2}$ receptor gene-disrupted (-/y) mice $(G-J)$ alone $(B, G)$ or in the presence of $10^{-6} \mathrm{M}$ ANG II $(C, H), 10^{-5} \mathrm{M}$ losartan $(D, I)$, and $10^{-6} \mathrm{PD}-123319(E, J)$. Scale bar, $1 \mathrm{~mm}$. Arrows point to losartan-sensitive [ $\left.{ }^{125} \mathrm{I}\right] \mathrm{Sar}^{1}$-ANG II binding to $\mathrm{AT}_{1}$ receptors located on glomeruli. Arrowheads point to losartan-insensitive $\left[{ }^{125} \mathrm{I}\right] \mathrm{Sar}^{1}$-ANG II binding to $\mathrm{AT}_{2}$ receptors that are absent in $\mathrm{AT}_{2}$ receptor gene-disrupted mice $(I)$. 
Table 1. ANG II receptor $A T_{1}$ binding and $m R N A$ in mouse kidney

\begin{tabular}{lccr}
\hline \hline & Wild-Type & $\mathrm{AT}_{2}$ Gene-Disrupted & \% Change \\
\hline $\begin{array}{l}\text { Glomeruli } \\
\text { Binding }\end{array}$ & $72 \pm 19$ & $164 \pm 5 \dagger$ & +127 \\
mRNA & $456 \pm 45$ & $695 \pm 63 \dagger$ & +52 \\
Rest of the cortex & & $27 \pm 5^{*}$ & +200 \\
$\quad \begin{array}{l}\text { Binding } \\
\text { mRNA }\end{array}$ & $9 \pm \pm 4$ & $134 \pm 32$ & +44 \\
$\begin{array}{l}\text { Outer stripe of the } \\
\text { outer medulla }\end{array}$ & & & \\
$\begin{array}{l}\text { Binding } \\
\text { mRNA }\end{array}$ & $8 \pm \pm 1$ & $15 \pm 2^{*}$ & +87 \\
$\begin{array}{l}\text { Inner stripe of the } \\
\text { outer medulla }\end{array}$ & $106 \pm 12$ & $166 \pm 27$ & +56 \\
$\begin{array}{l}\text { Binding } \\
\text { mRNA }\end{array}$ & $29 \pm 6$ & & \\
\hline
\end{tabular}

Values are means $\pm \mathrm{SE}$. Binding to ANGII type $1\left(\mathrm{AT}_{1}\right)$ receptors, as determined by quantitative autoradiography, is expressed in $\mathrm{fmol} / \mathrm{mg}$ protein. $\mathrm{AT}_{1}$ receptor $\mathrm{mRNA}$, determined by in situ hybridization, is expressed in $\mathrm{nCi} / \mathrm{g}$. $* P<0.05 ; \dagger P<0.001$, statistically significant differences between wild-type and $\mathrm{AT}_{2}$ gene-disrupted mice.

ceptors (Fig. 1D). To confirm the presence of $\mathrm{AT}_{2}$ receptors in the cortical structures distinct from glomeruli, we used $\mathrm{AT}_{2}$ receptor-selective $\left[{ }^{125} \mathrm{I}\right] \mathrm{CGP}$ 42112 binding (Fig. 4). All $\left[{ }^{125} \mathrm{I}\right] \mathrm{CGP}-42112$ binding was displaced by ANG II (Fig. 4B) and by the $\mathrm{AT}_{2}$ receptor-specific ligand $\mathrm{PD}-123319$ (Fig. $4 D$ ) but not by the $\mathrm{AT}_{1}$ receptor-specific ligand losartan (Fig. $4 C$ ).

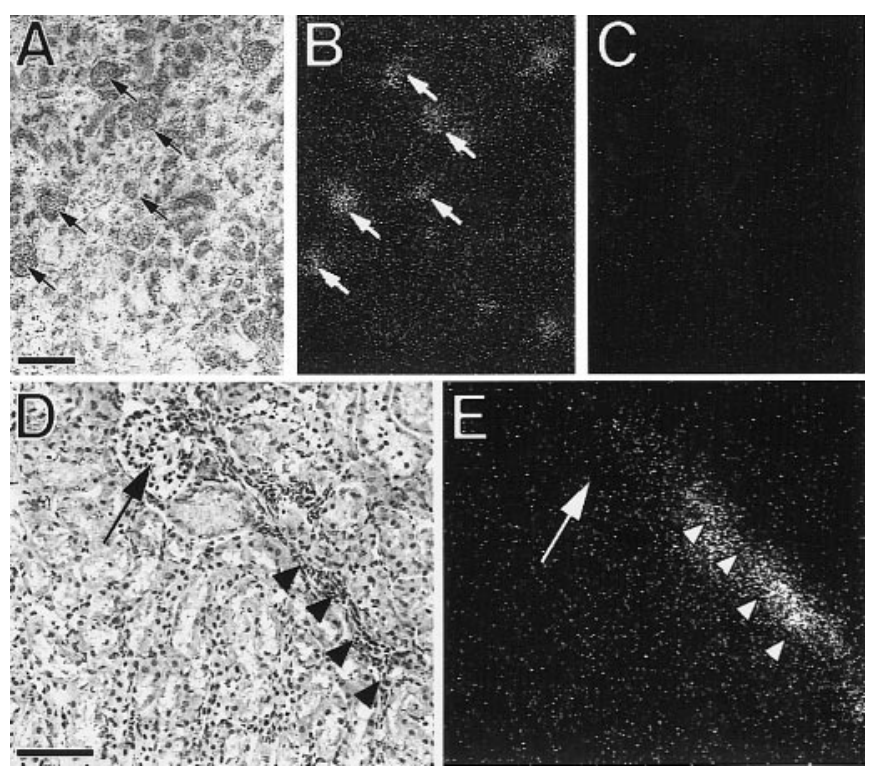

Fig. 2. Emulsion autoradiography of binding to $\mathrm{AT}_{1}$ and $\mathrm{AT}_{2}$ receptors in kidneys from male mice. Emulsion autoradiographs of binding of $0.5 \mathrm{nM}\left[{ }^{125} \mathrm{I}\right] \mathrm{Sar}^{1}$-ANG II to glomeruli of kidneys from $\mathrm{AT}_{2}$ receptor gene-disrupted (-/y) mice in the absence $(B)$ and presence of $10^{-5} \mathrm{M}$ losartan $(C)$. In addition, $\left[{ }^{125} \mathrm{I}\right] \mathrm{CGP}-42112$ binding is shown in vascular structures of kidneys from wild-type $(+/ \mathrm{y})$ mice $(E)$. $A$ and $D$ : histology of $B$ and $E$, respectively. $A$ and $D$ : arrows point to glomeruli. $D$ and $E$ : arrowheads point to a blood vessel. Scale bars, $60 \mu \mathrm{m}$. Scale bar in $A$ applies to $A$ - $C$. Scale bar in $D$ applies to $D$ and $E$.
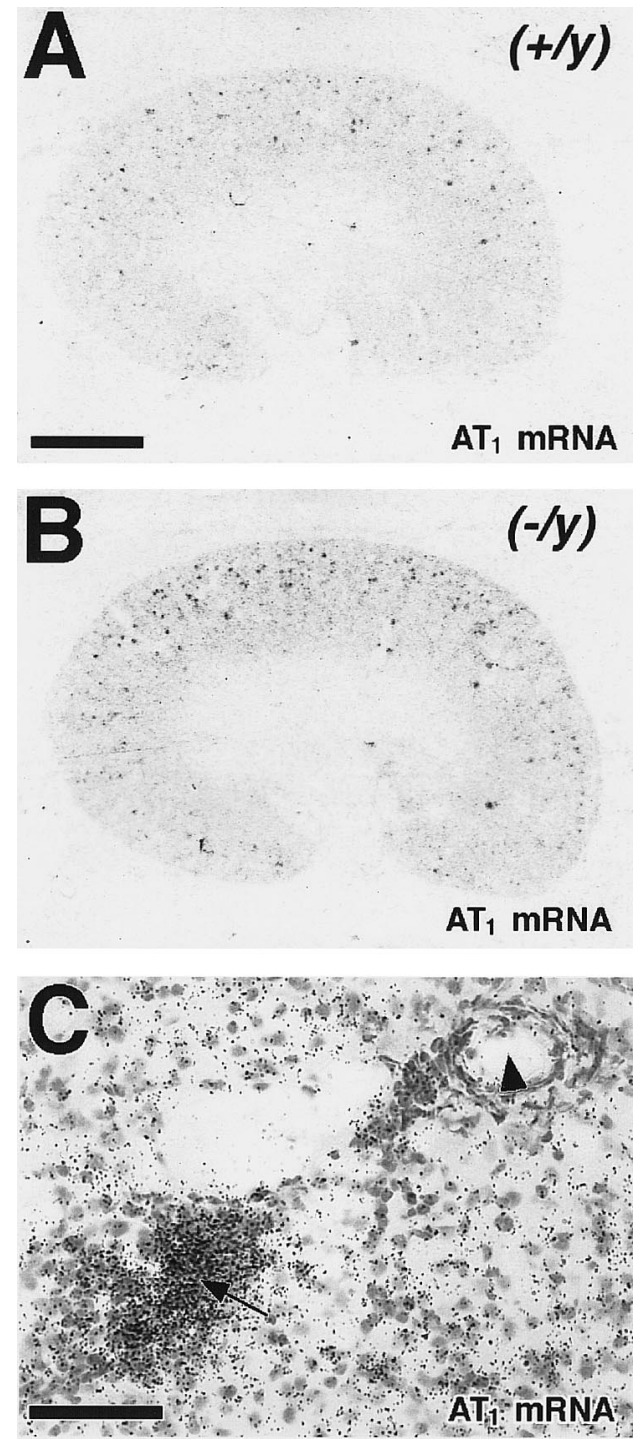

Fig. 3. Autoradiography of ANG II receptor subtype mRNA in kidneys from male mice. Film $(A$ and $B)$ and emulsion $(C)$ autoradiograms after in situ hybridization by using an $\mathrm{AT}_{1}$ receptor-specific riboprobe. $A$ : wild-type mice. $B$ : $\mathrm{AT}_{2}$ gene-disrupted mice. Note the presence of $\mathrm{AT}_{1}$ receptor mRNA in glomeruli from wild-type mice (arrow in $C$ ). $C$ : arrowhead points to a blood vessel. Scale bar in $A$ is $2 \mathrm{~mm}$ (also applies to $B$ ). Scale bar in $C$ is $250 \mu \mathrm{m}$.

Specific $\left[{ }^{125} \mathrm{I}\right] \mathrm{CGP}-42112$ binding sites were detected in the kidney cortex and, as determined by emulsion autoradiography, were associated only with vascular structures, in particular the arcuate arteries (Fig. 2, $D$ and $E$ ). Emulsion autoradiographic analysis of other structures in the kidney cortex, and in particular the kidney glomeruli, did not reveal accumulation of silver grains above background levels.

$A N G$ II $A T_{1}$ receptor expression and $m R N A$ in $A T_{2}$ gene-disrupted mice. As expected, the $\mathrm{AT}_{2}$ receptor gene-disrupted male did not express losartan-insensitive, PD-123319-sensitive $\left(\mathrm{AT}_{2}\right) \quad\left[{ }^{125} \mathrm{I}\right] \mathrm{Sar}^{1}$-ANG II binding sites (Fig. 1, $F-J$ ) or $\mathrm{AT}_{2}$ receptor-selective $\left[{ }^{125} \mathrm{I}\right] \mathrm{CGP}-42112$ binding (Fig. $4, E-H$ ) in the renal cortex or in other areas of the kidney. 


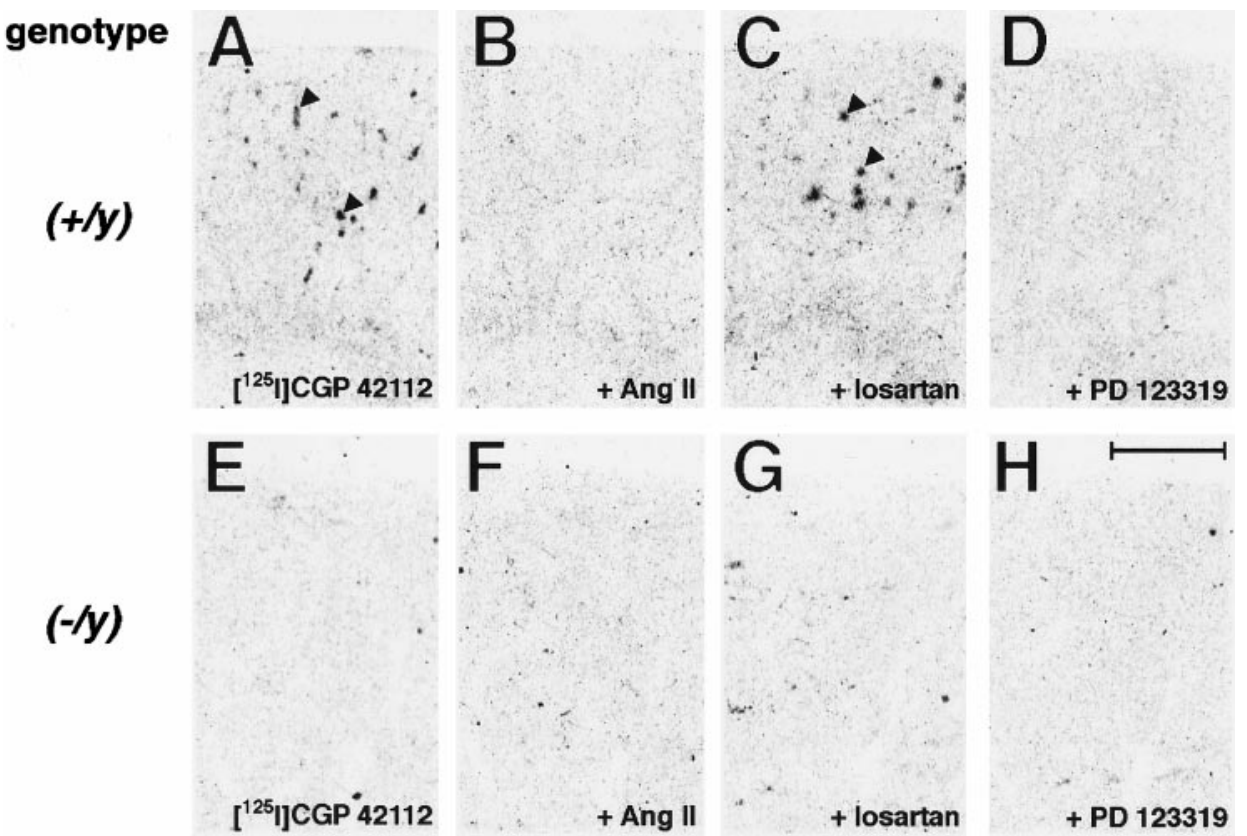

Fig. 4. Autoradiography of binding to $\mathrm{AT}_{2}$ receptors in kidneys from male mice. Binding of $0.2 \mathrm{nM}\left[{ }^{125} \mathrm{I}\right] \mathrm{CGP}-42112$ in kidneys of wild-type $(+/ \mathrm{y})$ mice $(A-D)$ and $\mathrm{AT}_{2}$ receptor gene-disrupted (-/y) mice $(E-H)$ alone $(A, E)$ and in the presence of $5 \times 10^{-6}$ ANG II $(B, F), 10^{-5} \mathrm{M}$ losartan $(C, G)$, and $10^{-6}$ PD-123319 (D, $H$ ). Arrowheads point to specific binding of $\left[{ }^{125} \mathrm{I}\right] \mathrm{CGP}-42112$ to $\mathrm{AT}_{2}$ receptors. Scale bar, $1 \mathrm{~mm}(A-H)$.
A remarkable difference in $\mathrm{ANG}$ II $\mathrm{AT}_{1}$ receptor binding studied with quantitative autoradiography, and mRNA, as determined by in situ hybridization, was noted in $\mathrm{AT}_{2}$ gene-disrupted mice compared with wild-type controls. In $\mathrm{AT}_{2}$ receptor gene-disrupted mice, both $\left[{ }^{125} \mathrm{I}\right] \mathrm{Sar}^{1}$-ANG II binding to $\mathrm{AT}_{1}$ receptors and $\mathrm{AT}_{1}$ receptor mRNA were higher compared with values in wild-type mice. Significant increases in $\mathrm{AT}_{1}$ receptor binding $(\sim 125 \%)$ (Table 1, Fig. $1, G$ and $J$ ) and $\mathrm{AT}_{1}$ mRNA $(\sim 50 \%)$ (Table 1, Fig. $3, B$ and $C$ ) were found in glomeruli.

Binding was significantly increased in the rest of the renal cortex (3-fold) and in the outer stripe of the outer medulla $(\sim 90 \%)$. In these areas there was a tendency toward increased expression of $\mathrm{AT}_{1}$ mRNA, a $\sim 45 \%$ increase in the rest of the renal cortex, and about a $\sim 55 \%$ increase in the outer stripe of the outer medulla (Table 1).

In the rest of the renal cortex and the outer stripe of the outer medulla of $\mathrm{AT}_{2}$ gene-disrupted mice, $\mathrm{AT}_{1}$ receptor expression was also significantly higher $(\mathrm{Ta}-$ ble 1). In these areas there was increased expression of $\mathrm{AT}_{1}$ mRNA, but the results did not achieve statistical significance (Table 1). Conversely, no significant differences were found in $\mathrm{AT}_{1}$ receptor binding or mRNA in the inner stripe of the outer medulla between wild-type animals and $\mathrm{AT}_{2}$ gene-deficient male mice (Table 1).

\section{DISCUSSION}

We report that gene disruption of the $\mathrm{ANG}$ II $\mathrm{AT}_{2}$ receptor results in marked and selective alterations on the protein and mRNA expression of the renal $\mathrm{AT}_{1}$ receptors in the male mouse.

First, we analyzed the distribution of $\mathrm{AT}_{1}$ receptor binding and mRNA in the kidney of wild-type male mice. The highest numbers of $\mathrm{AT}_{1}$ receptors and highest $\mathrm{AT}_{1}$ mRNA expression occur in the glomeruli, sig- nificant $\mathrm{AT}_{1}$ receptor binding, and $\mathrm{mRNA}$ in the inner stripe of the outer medulla, and lower binding and receptor mRNA in the rest of the kidney cortex. These results are in agreement with previous data from other mammalian species and with the demonstration of $\mathrm{AT}_{1}$ receptors, not only in glomeruli but also in proximal and distal tubules, medullar interstitial cells, and the vasculature $(1,4,6-10,22,23,30,36,38,40,48)$. In addition, we detected low levels of $\mathrm{AT}_{1}$ receptor binding, and significant levels of $\mathrm{AT}_{1}$ receptor mRNA, in the outer stripe of the outer medulla of wild-type mice. This indicates that some $\mathrm{AT}_{1}$ receptors may be located, in the mouse, in medullar structures that do not express $\mathrm{AT}_{1}$ receptors in the rat (47).

We found a clear expression of $\mathrm{AT}_{2}$ receptor binding in the kidney of the wild-type mice, a finding that again contrasts with the reported absence of $\mathrm{AT}_{2}$ receptors in adult rats $(1,4,5)$. The number of $\mathrm{AT}_{2}$ receptors in the adult mouse kidney was much lower than that of $\mathrm{AT}_{1}$ receptors, and followed a different pattern of localization. $\mathrm{AT}_{2}$ receptor binding was restricted to very selective cortical areas associated with renal vessels. This is in agreement with the reported localization of $\mathrm{AT}_{2}$ receptors in renal vessels of other species, including humans $(8,9,10,30,48)$. Under the conditions of our assay, we could not find $\mathrm{AT}_{2}$ receptor binding in kidney glomeruli and interstitial cells, as proposed with immunocytochemical techniques (38). If present, these receptors might be expressed in low amounts below the sensitivity of our assay.

Thus our analysis of ANG II receptor subtypes in the adult mice indicated that both receptors were clearly expressed, that the $\mathrm{AT}_{1}$ receptor predominated, and that the localization of the receptor subtypes occurred, at least for the most part, with exception of the vasculature, in separate renal structures. 
Next, we studied ANG II receptor subtype expression and mRNA in $\mathrm{AT}_{2}$ gene-disrupted mice. In the kidney of adult $\mathrm{AT}_{2}$ gene-disrupted mice there was no PD-123319-sensitive, losartan-insensitive binding and no $\left[{ }^{125} \mathrm{I}\right] \mathrm{CGP} 42112, \mathrm{AT}_{2}$-selective binding. The total absence of $\mathrm{AT}_{2}$ receptor binding in the $\mathrm{AT}_{2}$ gene-disrupted mouse was expected, because $\mathrm{AT}_{2}$ receptors are encoded by a single gene $(16,19,39)$, and confirmed the identity of $\mathrm{AT}_{2}$ receptor binding sites with the cloned $\mathrm{AT}_{2}$ receptor.

The main finding in our study was the demonstration of a significant increase in $\mathrm{AT}_{1}$ receptor expression and mRNA in the kidney of adult $\mathrm{AT}_{2}$ gene-disrupted mice. Ours is a clear example of how the gene disruption of one receptor can alter the expression of another receptor. This is particularly remarkable considering that the expression of renal $\mathrm{AT}_{2}$ receptors in wild-type mice is very low, compared with that of $\mathrm{AT}_{1}$ receptors. Our results further support the hypothesis that the level of expression of the $\mathrm{AT}_{2}$ receptors inversely correlates with that of $\mathrm{AT}_{1}$ receptors. Earlier studies demonstrated that the cardiac specific over-expression of $\mathrm{AT}_{2}$ receptors attenuates the $\mathrm{AT}_{1}$-mediated pressor and chronotropic effects of ANG II (29). In addition, $\mathrm{AT}_{2}$ receptors are highly expressed in the fetal kidney, and their numbers decrease during gestation in parallel with a concomitant increase in $\mathrm{AT}_{1}$ receptor expression (4).

Activation of $\mathrm{AT}_{1}$ and $\mathrm{AT}_{2}$ receptors in wild-type animals results in effects different, and in most cases opposite; and stimulation of $\mathrm{AT}_{2}$ receptors was postulated to limit the response of $\mathrm{AT}_{1}$ receptors to ANG II (17). Stimulation of kidney $\mathrm{AT}_{1}$ receptors decreases cortical and medullar blood flow and decreases urine flow and natriuresis, the principal renal effects of ANG II, shifting pressure natriuresis to the right (11). Conversely, in wild-type animals, stimulation of $\mathrm{AT}_{2}$ receptors was reported to increase pressure natriuresis (26) and their stimulation results in renal vasodilatation, probably as a consequence of production of cGMP, (42), nitric oxide (43), and prostaglandin F2 alpha (44), and increased arachidonic acid release $(20) . \mathrm{AT}_{1}$ receptor blockade produces vasodilatation, diuresis and natriuresis, and this was proposed to be due to unopposed $\mathrm{AT}_{2}$ receptor stimulation $(3,33,35,42)$. The evidence of a physiological role of renal $\mathrm{AT}_{2}$ receptors, however, is controversial. $\mathrm{AT}_{2}$ receptor blockade was reported to potentiate the ANG II-induced $\mathrm{PGE}_{2}$ production after $\mathrm{AT}_{1}$ receptor stimulation (42) and prevents the effect of ANG II on the vasculature (24). However, other studies indicate that chronic blockade of $\mathrm{AT}_{2}$ receptors in wildtype adult animals does not alter the response to $\mathrm{AT}_{1}$ receptor stimulation by ANG II (33).

In mice lacking $\mathrm{AT}_{2}$ receptor expression there is increased sodium retention, rightward shift in pressure natriuresis and diuresis, reduction in cortical and medullar blood flow, increased blood pressure, and enhanced hypertensive response to ANG II administration $(12,15,17)$. The phenotype of the $\mathrm{AT}_{2}$ receptor gene-disrupted mouse may be related to the upregulation of the $\mathrm{AT}_{1}$ receptor, rather than negatively reflect- ing the actions of the $\mathrm{AT}_{2}$ receptor $(12,45)$. It is also possible that the $\mathrm{AT}_{2}$ receptor gene-disrupted phenotype could be the result of a lost balance between $\mathrm{AT}_{1}$ and $\mathrm{AT}_{2}$ receptors, with a shift toward predominance of $\mathrm{AT}_{1}$-related effects. In addition, higher $\mathrm{AT}_{1}$ receptor transcription and expression could explain the enhanced fibrosis after ureteral occlusion in $\mathrm{AT}_{2}$ genedeficient mice $(25,28)$, because kidney fibrosis induced by ANG II is $\mathrm{AT}_{1}$ receptor dependent (27).

There is a recent report (12) of increased $\mathrm{AT}_{1}$ receptor mRNA in the whole kidney of $\mathrm{AT}_{2}$ gene-disrupted mice. Our findings of increased $\mathrm{AT}_{1}$ receptor binding indicate that an actual increase in $\mathrm{AT}_{1}$ receptor expression occurs in $\mathrm{AT}_{2}$ receptor gene-disrupted mice. In addition we demonstrate here that upregulation of renal $\mathrm{AT}_{1}$ receptors predominantly occurs in cortical structures, the kidney glomeruli, and probably in the tubular epithelium, and in the outer stripe of the outer medulla. In $\mathrm{AT}_{2}$ receptor gene-disrupted mice, there are no changes in $\mathrm{AT}_{1}$ receptor expression in the inner stripe of the outer medulla. Thus the $\mathrm{AT}_{1}$ upregulation and the $\mathrm{AT}_{2}-\mathrm{AT}_{1}$ feedback in this model are structure and cell specific. Although the expression of glomerular and cortical interstitial $\mathrm{AT}_{1}$ receptors may depend on $\mathrm{AT}_{2}$ receptor expression, the $\mathrm{AT}_{1}$ receptor expression in the inner stripe of the outer medulla does not. We conclude from our results that $\mathrm{AT}_{1}$ receptors in renal glomeruli, interstitial, and medullar cells are differentially regulated.

Last, our findings further support the hypothesis of a crosstalk or feedback between $\mathrm{AT}_{1}$ and $\mathrm{AT}_{2}$ receptor subtypes. It appears that $\mathrm{AT}_{1}$ receptors for the most part do not coexist with $\mathrm{AT}_{2}$ receptors in the same renal cells. For this reason, the mechanism of feedback is probably indirect, through modifications in kidney function related to the absence of $\mathrm{AT}_{2}$ receptors, and the upregulation of renal $\mathrm{AT}_{1}$ receptors.

In our model, when alterations in the transcription and expression of $\mathrm{AT}_{2}$ receptors are present from birth, renal $\mathrm{AT}_{1}$ receptor expression and consequently renal function, are profoundly affected in the adult. Because $\mathrm{AT}_{1}$ receptor antagonists are widely used in the treatment of cardiovascular disease, the crosstalk/feedback between $\mathrm{AT}_{1}$ and $\mathrm{AT}_{2}$ receptors has significant pathophysiological and clinical relevance.

W. Haüser was supported by a grant from ASTRA GmbH, Germany.

\section{REFERENCES}

1. Allen AM, Zhuo J, and Mendelsohn FAO. Localization of angiotensin $\mathrm{AT}_{1}$ and $\mathrm{AT}_{2}$ receptors. J Am Soc Nephrol 10: $\mathrm{S} 23-$ S29, 1999.

2. Ardaillou R. Angiotensin II receptors. J Am Soc Nephrol 10: S30-S39, 1999.

3. Arima S, Endo Y, Yaoita H, Omata K, Ogawa S, Tsunoda K, Abe M, Takeuchi K, Abe K, and Ito S. Possible role of P-450 metabolite of arachidonic acid in vasodilator mechanism of angiotensin II type 2 receptor in the isolated microperfused rabbit afferent arteriole. J Clin Invest 100: 2816-2823, 1997.

4. Ciuffo GM, Viswanathan M, Seltzer AM, Tsutsumi K, and Saavedra JM. Glomerular angiotensin II receptor subtypes during development of rat kidney. Am J Physiol Renal Fluid Electrolyte Physiol 265: F264-F271, 1993. 
5. Correa FMA, Viswanathan M, Ciuffo GM, Tsutsumi K, and Saavedra JM. Kidney angiotensin II receptors and converting enzyme in neonatal and adult Wistar-Kyoto and spontaneously hypertensive rats. Peptides 16: 19-24, 1995.

6. de Gasparo M and Levens NR. Pharmacology of angiotensin II receptors in the kidney. Kidney Int 46: 1486-1491, 1994.

7. Gasc JM, Shanmugam S, Sibony M, and Corvol P. Tissuespecific expression of type 1 angiotensin II receptor subtypes. An in situ hybridization study. Hypertension 24: 531-537, 1994.

8. Gibson RE, Thorpe HH, Cartwright ME, Frank JD, Schorn TW, Bunting PB, and Siegl PK. Angiotensin II receptor subtypes in renal cortex of rats and rhesus monkeys. Am J Physiol Renal Fluid Electrolyte Physiol 261: F512-F518, 1991.

9. Goldfarb DA, Diz DI, Tubbs RR, Ferrario CM, and Novick AC. Angiotensin II receptor subtypes in the human renal cortex and renal cell carcinoma. J Urol 151: 208-213, 1994.

10. Gröne HJ, Simon M, and Fuchs E. Autoradiographic characterization of angiotensin receptor subtypes in fetal and adult human kidney. Am J Physiol Renal Fluid Electrolyte Physiol 262: F326-F331, 1992.

11. Gross V, Lippoldt A, Schneider W, and Luft FC. Effect of captopril and angiotensin II receptor blockade on pressure natriuresis in transgenic (mRen2) 24 rats. Hypertension 26: 471479, 1995.

12. GrossV, Schunck WH, Honeck H, Milia AF, Kargel E, Walther T, Bader M, Inagami T, Schenider W, and Luft FC. Inhibition of pressure natriuresis in mice lacking the $\mathrm{AT}_{2}$ receptor. Kidney Int 57: 191-202, 2000.

13. Häuser W, Jöhren O, and Saavedra JM. Characterization and distribution of angiotensin II receptor subtypes in the mouse brain. Eur J Pharmacol 348: 101-114, 1998.

14. Heemskerk FMJ and Saavedra JM. Quantitative autoradiography of angiotensin II $\mathrm{AT}_{2}$ receptors with [ $\left.{ }^{125} \mathrm{I}\right] \mathrm{CGP} 42112$. Brain Res 677: 29-38, 1995.

15. Hein L, Barsh GS, Pratt RE, Dzau VJ, and Kobilka BK. Behavioral and cardiovascular effects of disrupting the angiotensin II type-2 receptor gene in mice. Nature 377: 744-747, 1995.

16. Ichiki T, Herold CL, Kambayashi Y, Bardhan S, and Inagami T. Cloning of the cDNA and the genomic structure of the mouse angiotensin II type 2 receptor. Biochim Biophys Acta 1189: 247-250, 1994.

17. Ichiki T, Labosky PA, Shiota C, Okuyama S, Imagawa Y, Fogo A, Niimura F, Ichikawa I, Hogan BLM, and Inagami T. Effects on blood pressure and explorative behaviour of mice lacking angiotensin II type-2 receptor. Nature 377: 748-750, 1995.

18. Ichiki T and Inagami T. Expression, genomic organization and transcription of the mouse angiotensin II type 2 receptor gene. Circ Res 76: 693-700, 1995.

19. Iwai N, Yamano Y, Chaki S, Konishi F, Bardhan S, Tibbetts C, Sasaki K, Hasegawa M, Matsuda Y, and Inagami T. Rat angiotensin II receptor: cDNA sequence and regulation of the gene expression. Biochem Biophys Res Commun Commun177: 299-304, 1991.

20. Jacobs LS and Douglas JG. Angiotensin II type 2 receptor subtype mediates phospholipase $\mathrm{A}_{2}$-dependent signaling in rabbit proximal tubular epithelial cells. Hypertension 28: 663-668, 1996.

21. Jöhren O, Inagami $\mathbf{T}$, and Saavedra JM. $\mathrm{AT}_{1 \mathrm{~A}}, \mathrm{AT}_{1 \mathrm{~B}}$ and $\mathrm{AT}_{2}$ angiotensin II receptor subtype gene expression in rat brain. Neuroreport 6: 2549-2552, 1995.

22. Kakinuma Y, Fogo A, Inagami T, and Ichikawa I. Intrarenal localization of angiotensin II type 1 receptor mRNA in the rat. Kidney Int 43: 1229-1235, 1993.

23. Kakuchi J, Ichiki T, Kiyama S, Hogan BLM, Fogo A, Inagami T, and Ichikawa I. Developmental expression of renal angiotensin II receptor genes in the mouse. Kidney Int 47: 140-147, 1995.

24. Levy BI, Benessiano J, Henrion D, Caputo L, Heymes C, Duriez M, Poitevin P, and Samuel JM. Chronic blockade of $\mathrm{AT}_{2}$-subtype receptors prevents the effect of angiotensin II on the rat vascular structure. J Clin Invest 98: 418-425, 1996.
25. Li WG, Chen WM, Ye YZ, Ichiki T, and Inagami T. Longterm effects of angiotensin II type $2\left(\mathrm{AT}_{2}\right)$ receptor null mutation on renal fibronectin deposition and PA/PAI-1 regulation. $J$ Am Soc Nephrol 9: 502A, 1998.

26. Lo M, Liu KL, Lantelme P, and Sassard J. Subtype 2 of angiotensin II receptors controls pressure-natriuresis in rats. J Clin Invest 95: 1394-1397, 1995.

27. Lombardi DM, Viswanathan M, Vio CP, Saavedra JM, Schwarz SM, and Johnson RJ. Renal and vascular injury induced by exogenous angiotensin II is $\mathrm{AT}_{1}$ receptor dependent. Nephron in press.

28. Ma J, Nishimura H, Fogo A, Kon V, Inagami T, and Ichikawa I. Accelerated fibrosis and collagen deposition develop in the renal interstitium of angiotensin type 2 receptor null mutant mice during ureteral obstruction. Kidney Int 53: 937944, 1998.

29. Masaki H, Kurihara T, Yamaki A, Inomata N, Nozawa Y, Mori Murasawa S, Kizima K, Maruyama K, Horiuchi M, Dzau VJ, Takahashi H, Iwasaka T, Inada M, and Matsubara H. Cardiac-specific overexpression of angiotensin II $\mathrm{AT}_{2}$ receptor causes attenuated response to $\mathrm{AT}_{1}$ receptor-mediated pressor and chronotropic effects. J Clin Invest 101: 527-535, 1998.

30. Matsubara H, Sugaya T, Murasawa S, Nozawa Y, Mori Y, Masaki H, Maruyama K, Tsutumi Y, Shibasaki Y, Moriguchi Y, Tanaka Y, Iwasaka T, and Inada M. Tissue-specific expression of human angiotensin II $\mathrm{AT}_{1}$ and $\mathrm{AT}_{2}$ receptors and cellular localization of subtype mRNAs in adult human renal cortex using in situ hybridization. Nephron 80: 25-34, 1998.

31. Matsusaka T and Ichikawa I. Biological functions of angiotensin and its receptors. Annu Rev Physiol 59: 395-412, 1997.

32. Miller JA. The calibration of ${ }^{35} \mathrm{~S}$ or ${ }^{32} \mathrm{P}$ with ${ }^{14} \mathrm{C}$-labeled brain paste or ${ }^{14} \mathrm{C}$-plastic standards for quantitative autoradiography using LKB Ultrofilm or Amersham Hyperfilm. Neurosci Lett 121: 211-214, 1991

33. Muller C, Endlich K, and Helwig JJ. $\mathrm{AT}_{2}$ antagonist-sensitive potentiation of angiotensin II-induced constriction by NO blockade and its dependence on endothelium and P450 eicosanoids in rat renal vasculature. Br J Pharmacol 124: 946-952, 1998.

34. Munoz-Garcia R, Maeso R, Rodrigo E, Navarro J, Ruilope LM, Casal MC, Cachofeiro V, and Lahera V. Acute renal excretory actions of losartan in spontaneously hypertensive rats: role of $\mathrm{AT}_{2}$ receptors, prostaglandins, kinins and nitric oxide. J Hypertens 13: 1779-1784, 1995.

35. Munzenmaier DH and Greene AS. Opposing actions of angiotensin II on microvascular growth and arterial blood pressure. Hypertension 27[part 2]: 760-765, 1996.

36. Navar LG, Harrison-Bernard LM, Wang CT, Cervenka L, and Mitchell KD. Concentrations and actions of intraluminal angiotensin II. J Am Soc Nephrol 10: S189-S195, 1999.

37. Nazarali AJ, Gutkind JS, and Saavedra JM. Calibration of $\left[{ }^{125} \mathrm{I}\right]$-polymer standards with $\left[{ }^{125} \mathrm{I}\right]$-brain paste standards for use in quantitative receptor autoradiography. J Neurosci Methods 30: 247-253, 1989 .

38. Ozono R, Wang ZQ, Moore AF, Inagami T, Siragy HM, and Carey RM. Expression of the subtype 2 angiotensin $\left(\mathrm{AT}_{2}\right)$ receptor protein in rat kidney. Hypertension 30: 1238-1246, 1997.

39. Sasamura H, Hein L, Krieger JE, Pratt RE, Kobilka BK, and Dzau VJ. Cloning, characterization, and expression of two angiotensin receptor (AT-1) isoforms from the mouse genome. Biochem Biophys Res Commun 185: 253-259, 1992.

40. Sechi LA, Grady EF, Griffin CA, Kalinyak JE, and Schambelan M. Distribution of angiotensin II receptor subtypes in rat and human kidney. Am J Physiol Renal Fluid Electrolyte Physiol 262: F236-F240, 1992.

41. Shanmugan $\mathbf{S}$ and Sandberg K. Ontogeny of angiotensin receptors. Cell Biol Int 20: 169-176, 1996.

42. Siragy HM and Carey RM. The subtype- $2\left(\mathrm{AT}_{2}\right)$ angiotensin receptor regulates renal cyclic guanosine $3^{\prime}, 5^{\prime}$-monophosphate and $\mathrm{AT}_{1}$ receptor-mediated prostaglandin $\mathrm{E}_{2}$ production in conscious rats. J Clin Invest 97: 1978-1982, 1996. 
43. Siragy HM and Carey RM. The subtype $2\left(\mathrm{AT}_{2}\right)$ angiotensin receptor mediates renal production of nitric oxide in conscious rats. J Clin Invest 100: 264-269, 1997.

44. Siragy HM and Carey RM. The subtype 2 angiotensin receptor regulates renal prostaglandin $\mathrm{F} 2$ alpha formation in conscious rats. Am J Physiol 27: R1103-R1107, 1997.

45. Siragy HM, Inagami T, Ichiki T, and Carey RM. Sustained hypersensitivity to angiotensin II and its mechanism in mice lacking the subtype-2 $\left(\mathrm{AT}_{2}\right)$ angiotensin receptor. Proc Natl Acad Sci USA 96: 6506-6510, 1999.

46. Timmermans PB, Wong PC, Chiu AT, Herblin WF, Benfield P, Carini DJ, Lee RJ, Wexler RR, Saye JA, and Smith
RD. Angiotensin II receptors and angiotensin II receptor antagonists. Pharmacol Rev 45: 205-251, 1993.

47. Wisden W and Morris BJ. In situ hybridization with synthetic oligonucleotide probes. In: In Situ Hybridization Protocols for the Brain, edited by Wisden W and Morris BJ. New York: Academic, 1994, p. 9-34.

48. Zhuo J, Alcorn D, Allen AM, and Mendelsohn FAO. High resolution localization of angiotensin II receptors in rat renal medulla. Kidney Int 42: 1372-1380, 1992.

49. Zhuo J, Dean R, MacGregor D, Alcorn D, and Mendelsohn FAO. Presence of angiotensin II $\mathrm{AT}_{2}$ receptor binding sites in the adventitia of human kidney vasculature. Clin Exp Pharmacol Physiol 3: S147-S153, 1996.

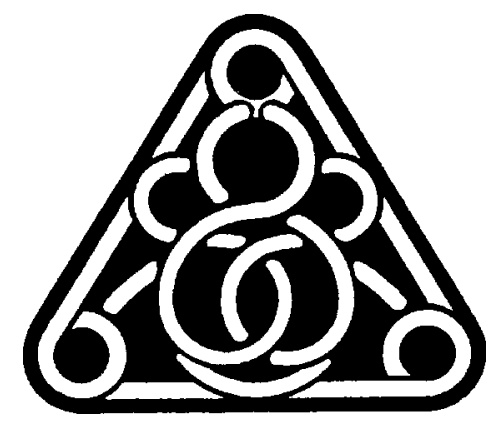

